\title{
Learning Tools with Inquiry Models Integrated of Character Education
}

\author{
Irham Azmi ${ }^{\left.{ }^{*}\right)}$, A. Wahab Jufri ${ }^{2)}$, Muh. Makhrus ${ }^{3)}$ \\ 1) Natural Sciences Education Study Program, Universitas Mataram. Jln. Majapahit \\ No.62 Mataram, Indonesia
}

*Corresponding Author Email: irhamazmi94@gmail.com

\section{Article History}

Received: March 2020

Accepted: April 2020

Published: June 2020

Key Words

Learning tools;

inquiry model;

character education

How to cite this article?

\begin{abstract}
This study aimed to describe the characteristics and validity of learning tools with inquiry models integrated of character education that is used in learning at junior high school level. The intended learning tools include syllabus, lesson plans, teaching materials, student worksheets, and scientific creativity test instruments. This research is an evaluative descriptive study that describes the characteristics and evaluates the quality of the validity of learning tools. The learning tools validation process involves three validators who validate the learning tools on aspects of content validity and construct validity. The validation results show that the validator's assessment of the learning framework developed in the aspects of content validity and construct validity are categorized as very valid with an average range of scores of $>85 \%$, with a percentage of agreement $>75 \%$. The results of this study can be used as a foundation that the learning tools with inquiry models integrated of character education can be implemented in the field.
\end{abstract}

Azmi, I., Jufri, A., \& Makhrus, M. (2020). Learning Tools with Inquiry Models Integrated of Character Education. Lensa: Jurnal Kependidikan Fisika, 8(1), 17-24. doi:https://doi.org/10.33394/j-1kf.v8i1.2750

\section{INTRODUCTION}

Learning tools are instruments to carry out the processes that enable educators and students to conducted learning activities. Learning tools are used as a reference by educators in the implementation of learning in the classroom, laboratory, or outside the classroom. Learning tools reflect the consistency between the parts of the set of learning tools and the suitability of the learning objectives, learning materials, and assessments that will be given, while the learning process occurs in many ways namely direct learning and some indirect such as distance learning (Rajabi et al., 2015). Learning requires learning tools with an approach that is able to develop students' thinking skills in understanding concepts correctly (Makhrus \& Hadi, 2012). The learning process takes place between educators and students which makes it possible for educators to recognize the characteristics and potential of the students (Larlen, 2013). Therefore, every educator in the education unit is obliged to arrange learning tools in accordance with the demands of the 21 st century, namely; critical, creative, communicative, and collaborative, as well as scientific literacy abilities.

Learning in the previous century emphasized literacy in reading, writing, and mathematics, where in the 21 st century they were used as the basis for developing new literacy, namely human, data and technological literacy which is very important to deal with the current era of globalization and in the future. (Muhali, 2019). Partnership for 21st Century Learning requires students to have skills, knowledge, abilities in the fields of technology, media and information, learning and innovation skills as well as life and 
career skills (P21, 2015). Learning in the 21st century must more than explain what is thought by educators where the 21 st century is a century that asks for quality and competence in all endeavors and work results or human skills (Jufri, 2017). Competence and skills are needed effectively in the 21st century, and knowledge is needed to stimulate students' abilities in learning (Scott, 2015). In Indonesia, the revised edition of the 2013 and 2018 curriculum is related to the dimension of knowledge that students are required to understand three main dimensions, namely: factual, conceptual, and procedural, while in the realm of skills are required to think and act like trying, processing, and serving (Permendikbud, 2016; 2018). Kratwohll in Jufri (2017) explains that the dimension of knowledge starts from the concrete to the abstract, from factual, conceptual, procedural, and metacognition.

Today's learning tools have not fully met the demands in question, where the demands of the 21st Century are referred to as the century of knowledge-based economics, the age of information technology, globalization, industrial revolution 4.0, and so on. However, in the world of education a fundamental change has been felt at the level of philosophy, direction and purpose. It's no exaggeration to say that the progress of science was triggered by the birth of computer science and technology. Advances in science and technology, especially in the fields of cognitive science, bio-molecular, information technology and nano-science then became a group of science that characterizes the 21 st century (Wijaya et al, 2016). Science learning is a process carried out by educators and students in studying natural phenomena and events aimed at gaining knowledge, skills, changing attitudes towards a positive direction (Asy'ari et al., 2018).

The learning tools developed in this study use inquiry models that are integrated in character education, where inquiry activities or scientific inquiry can develop students' thinking abilities to design their own or group inquiry (Masruroh et al., 2016). The learning model that supports the principles of scientific inquiry is the inquiry model (Suhartini et al., 2016). The goal of inquiry-based learning is to develop students 'desires and motivations to learn the principles and concepts of science, develop students' scientific skills so they are able to work like scientists, accustoming students to work hard to gain knowledge. Inquiry-based learning can make students learn science, and the inquiry process provides opportunities for students to have real and active learning experiences, so that students are trained in how to solve problems and make decisions. The teacher in inquiry learning is only as a guide or controller for students. The learning process requires students to learn, so the teacher adjusts to the activities carried out by students. Learning is oriented to the development of thinking skills and can be an alternative to improving students' thinking abilities in understanding a concept (Fitriana, 2016).

Inquiry learning model as a learning model that aims to teach students how to think. The task of learning in an inquiry learning plan is goal-oriented content and process (Arends, 2012). The intended content goal is, the teacher wants students to acquire new knowledge related to their focus in an investigation. While the purpose of the process, the teacher also wants students to learn the process of inquiry, especially those related to scientific inquiry, to develop a positive attitude towards what is done by students. Knowledge and representation obtained by students are expected not to be the result of remembering a set of facts, but rather the result of finding a scientific solution. Inquiry learning is one of the learning models that play an important role in building learning paradigms that emphasize student learning activeness.

Character education is the value of human behavior related to oneself, fellow human beings, the environment, and nationality that is manifested in thoughts, attitudes, feelings, words, and actions based on religious norms, law, etiquette, culture, and customs (Hasanah, 2016). Integrating character education needs to be done to ensure learning 
material has instructional or accompaniment impacts. According to Marzuki (2012) that teachers are required to master a variety of methods, models, or learning strategies so that the learning steps are easily arranged so that they can evaluate. The character of students is formed through a learning process and becomes an urgent matter to influence the future of one's life (Dianti, 2014).

Integrating character education in this learning tool aims to ensure learning material has a relevant impact on the development of students, in accordance with the character values developed in the Ministry of National Education, among others: religious, honest, discipline, tolerance, hard work, creative, independent, democratic, curiosity, national spirit, love of the motherland, respect for achievement, friendship, love for peace, love to read, care for the environment, care for the social, and responsible. Character education is more about the process that forms a school, home, and community environment which can jointly give birth to a good atmosphere and personality for students. The aspects of character education include; morality, religion, and psychological aspects. These three aspects are inseparable in character education learning (Maemunah, 2012). Good character education should start at home, because schools only help students to develop character (Asyhari et al., 2014). Character is a way of thinking and behaving that characterizes each individual to live and cooperate, both within the scope of the family, community, nation and state (Muryati, 2013). Character education through the treatment of children with great affection, as well as in the school and community environment (Laksana, 2015). Budur (2013) states that the percentage of cognitive learning outcomes of students increases. The increase in learning outcomes occurs because at each stage of learning it is integrated with character education especially character carefully, such as reading questions carefully so students can answer questions as expected.

Based on these descriptions, it is important to develop inquiry learning models that are integrated in character education, so that science learning can be learned in schools and can make a significant contribution in developing student behavior (Sadia et al., 2013). According to Zubaidah (2019) that the character of education is the acquisition and strengthening of virtue, values, and capacity to make wise choices in a holistic life. The statement is in accordance with the learning tool integrated inquiry model of character education that emphasizes students to think scientifically and have good ethics in learning. The expected results in this study are appropriate learning tools that can be used as references and provide appropriate stimulus in the learning process so that the potential for conducting scientific investigations and character education is facilitated in the learning process.

\section{METHOD}

This study aims to describe the characteristics and validity of learning tools with inquiry models integrated of character education that is used in learning at junior high school level. The intended learning tools include syllabus, lesson plans, teaching materials, student worksheets, and scientific creativity test instruments. This research is an evaluative descriptive study that describes the characteristics and evaluates the quality of the validity of learning tools. The learning tools validation process involves three validators who validate the learning tools on aspects of content validity and construct validity (Nieveen, 1999). Validity assessment uses a Likert scale with a gradation of each score from very valid, valid, enough valid, and not valid. Validity scores (NA) of three validators were averaged to get the final validity score of the learning tools. Based on the NA scores obtained, validity criteria are set as in Table 1. 
Table 1. Validity criteria of learning tools (Arikunto, 2010).

\begin{tabular}{cccl}
\hline Interval score & Validity percentage & Criteria & \multicolumn{1}{c}{ Annotation } \\
\hline 1 & $0-25$ & Not valid & Cannot be used \\
2 & $26-50$ & Enough valid & $\begin{array}{l}\text { Can be used with many } \\
\text { revisions } \\
\text { Can be used with a few } \\
\text { revision } \\
\text { Can be used without } \\
\text { revision }\end{array}$ \\
\hline
\end{tabular}

The average validity score of the learning tool is determined based on the score given by the validator. The reliability of learning tool is calculated using the percentage of agreement equation (Borich, 1994), it is said to be reliable if it has a percentage of agreement above $75 \%$.

Percentage Agreement $=\left(1-\frac{\mathrm{A}-\mathrm{B}}{\mathrm{A}+\mathrm{B}}\right) \times 100 \%$

Annotation:

$\mathrm{A}=$ Frequencies observed by observers who provide high frequencies.

$\mathrm{B}=$ Frequency observed by other observers who provide low frequencies.

\section{RESULTS AND DISCUSSION}

The development of learning tool product begins with identifying general learning objectives, instructional analysis, character analysis of students, formulating objectives, developing assessment instruments, developing learning strategies, developing and selecting materials. Based on these stages the product development results obtained in the form of syllabus, lesson plans, teaching materials, students woorksheet, and evaluation instruments. The characteristics of learning tools are described in Table 2.

Table 2. Characteristics of learning tools

\begin{tabular}{|c|c|}
\hline Components & Characteristics of learning tools \\
\hline Syllabus & $\begin{array}{l}\text { The syllabus is developed using the subject matter of motion } \\
\text { and force with material components namely: analyzing } \\
\text { straight motion, the effect of force on motion based on } \\
\text { Newton's laws, and its application to the motion of objects and } \\
\text { motion of living things, while the skill stage is to present the } \\
\text { results of an investigation related to the influence of force on } \\
\text { object motion. }\end{array}$ \\
\hline Lesson plans & $\begin{array}{l}\text { The learning model used at the learning activity stage } \\
\text { presented in the lesson plans is the Inquiry model by } \\
\text { integrating of character education. }\end{array}$ \\
\hline Teaching materials & $\begin{array}{l}\text { Teaching materials developed are integrated character } \\
\text { education which has characteristics in the form of text, } \\
\text { graphics, pictures, scientific biographies, and trigger questions } \\
\text { that foster students' scientific creativity. }\end{array}$ \\
\hline Students woorksheet & $\begin{array}{l}\text { Student worksheets arranged in stages of the inquiry learning } \\
\text { model }\end{array}$ \\
\hline $\begin{array}{l}\text { Evaluation } \\
\text { instruments }\end{array}$ & $\begin{array}{l}\text { The instrument of scientific creativity uses a combination of } 3 \\
\text { dimensions, namely process, trait, and product }(\mathrm{Hu} \& \text { Adey, } \\
\text { 2002). Scientific creativity is focused on scientific }\end{array}$ \\
\hline
\end{tabular}




\begin{tabular}{ll}
\hline Components & \multicolumn{1}{c}{ Characteristics of learning tools } \\
\hline & $\begin{array}{l}\text { experiments, problem solving and the search for answers and } \\
\text { creative scientific activities. }\end{array}$
\end{tabular}

The characteristics of the inquiry learning model integrated with character education in this study are specifically for learning in students at the junior high school level. The learning tools developed was then validated by three validators.

The validation process is carried out twice, where the results of the first validation show that the percentage of validity in the syllabus component is $56.5 \%$ with valid criteria, but it still needs to be improved. As for suggestions for improvement on this component in the form of adjustments to the syllabus component according to Ministry of Education and Culture Regulation No. 22 year of 2016 concerning the standards of the primary and secondary education process, assessment instruments must be adjusted to what will be assessed, and time allocation must be relevant to the level of material difficulty. The lesson plans component obtained $75.29 \%$ with valid criteria, but it still needs to be improved in the components of the learning phase. The teaching material component was $70.7 \%$, the students woorksheet component was $72.61 \%$, the question instrument component was $70 \%$, all three were valid criteria with some minor improvements. The validator's suggestion is then accommodated to improve the learning tools. The learning tools that has been improved is then re-validated (second validation). The final validation results are presented in Table 3.

Table 3. Learning tools validation results

\begin{tabular}{lccccc}
\hline \multicolumn{1}{c}{$\begin{array}{c}\text { Learning tool } \\
\text { components }\end{array}$} & $\mathrm{V}_{1}(\%)$ & $\mathrm{V}_{2}(\%)$ & $\mathrm{V}_{3}(\%)$ & Average (\%) & Criteria \\
\hline Syllabus & 87,5 & 92,7 & 94,5 & 91,6 & Very valid \\
Lesson plans & 85,5 & 80,3 & 89,5 & 85,1 & Very valid \\
Teaching materials & 88,7 & 92,6 & 91,9 & 91,1 & Very valid \\
Students woorksheet & 91,3 & 79,8 & 86,5 & 85,9 & Very valid \\
Evaluation instruments & 90,0 & 90,0 & 90,0 & 90,0 & Very valid \\
\hline
\end{tabular}

The results of the validation in Table 3 show that the average validity of the learning tools in the syllabus component was $91.6 \%$ with very valid criteria, then the lesson plan component was obtained $85.1 \%$ with a very valid criteria, then the teaching material component was $91.1 \%$ with very valid criteria, then the students worksheet component obtained $85.9 \%$ with a very valid criteria, and the last is the component of the evaluation instrument obtained $90 \%$ with very valid criteria. After the validity test results are obtained, then the reliability test is conducted between the validators. The results obtained are presented in Table 4.

Table 4. Reliabily results

\begin{tabular}{lccccc}
\hline \multicolumn{1}{c}{ Learning tool } & $\mathrm{V}_{1.2}(\%)$ & $\mathrm{V}_{1.3}(\%)$ & $\mathrm{V}_{2.3}(\%)$ & Average (\%) & Criteria \\
\hline Syllabus & 97,11 & 96,15 & 99,03 & 97,43 & Reliabel \\
Lesson plans & 96,86 & 97,71 & 94,58 & 96,38 & Reliabel \\
Teaching materials & 97,84 & 98,22 & 99.62 & 65,35 & Reliabel \\
Students woorksheet & 93,28 & 97,30 & 95,97 & 95,52 & Reliabel \\
Evaluation instruments & 100 & 100 & 100 & 100 & Reliabel \\
\hline
\end{tabular}


The reliability of learning tools is calculated using the percentage of agreement equation with a score of each syllabus component of $95.5 \%$, lesson plans of $94.1 \%$, teaching materials at $97.2 \%$, students worksheet at $92.8 \%$, and evaluation instruments at $100 \%$. These results indicate that the learning tools developed is reliable, because the standard of learning tools reliability if it has a percentage of agreement above $75 \%$.

Learning tool is said to be feasible to be used if it meets the criteria of content and construct validity, where content validity consists of needs that are developed, and the novelty of those developed in this case is an inquiry model integrated of character education in a learning tools. Good content validity must be used with a variety of methods, both qualitatively or quantitatively, with the aim of reducing variations in the potential for errors in making learning tools and increasing the likelihood of obtaining construct validity indices in further studies (Ihsan, 2015).

The National Science Education Standards (NSES) and National Research Council (NRC) in Wenning (2015) state that scientific inquiry is an activity that refers to a variety of ways in which scientists study nature and make explanations based on evidence obtained from the results investigation. Inquiry also refers to learning activities, where they develop knowledge and understanding of scientific ideas, as well as an understanding of how they study nature. Hussain et al (2011) defines inquiry as activities that involve observation, ask questions, examine sources of information to confirm what is already known, plan investigations, carry out experiments, use tools to collect, analyze and interpret data, propose answers, explanations, and predictions, and communicate the results.

Experts and researchers have done a lot of development and modification of inquiry with many terms including, namely: traditional inquiry, guided inquiry, structured inquiry, open inquiry, direct inquiry, inquiry learning, inquiry teaching, authentic inquiry, scientific inquiry, partial inquiry, and full inquiry (Buck et al., 2008). Based on this theory, learning tool in this study uses the inquiry model with stages of identifying objectives, making hypotheses, collecting and analyzing data, and assessing hypotheses and making conclusions.

Character education is more about the process that forms a school, home, and community environment which can jointly give birth to a good atmosphere and personality for students. The aspects of characters education include of morality, religion, and psychological aspects. These three aspects are inseparable in character education learning (Maemunah, 2012). Good character education should start at home, because schools only help students to develop character (Asyhari et al., 2014). Character is a way of thinking and behaving that characterizes each individual to live and cooperate, both within the scope of the family, community, nation and state (Muryati, 2013).

\section{CONSLUSSION}

The results of this study showed that the learning tools with inquiry models integrated of character education was valid based on the validator's judgement with an average score above $85 \%$. For the reliability of learning tools using the percentage of agreement equation with an average score exceeding $75 \%$ and declared reliable. The results of this study can be used as a foundation that the learning tools with inquiry models integrated of character education can be implemented in the field.

\section{REFERENCES}

Arends, R. (2012). Learning to Teach. Ninth Edition. New York: McGraw-Hill. Arikunto, S. (2010). Prosedur Penelitian Suatu Pendekatan Praktik. Jakarta: Rhineka Cipta. 
Asy'ari, M., Ikhsan, M., \& Muhali. (2018). Validitas Instrumen Karakterisasi Kemampuan Metakognisi Mahasiswa Calon Guru Fisika. Prisma Sains: Jurnal Pengkajian Ilmu dan Pembelajaran Matematika dan IPA IKIP Mataram, 6(1), 18-26.

Asyhari, A., Sunarno, W., Sarwanto. (2014). Pengembangan Perangkat Pembelajaran Fisika SMA Berbasis Inkuiri Terbimbing Terintegrasi Pendidikan Karakter. Jurnal Inkuiri. 3(1), 62-75.

Borich, Gary, D. (1994). Observation Skills for Effective Teaching. New York: Merrill.

Buck, L. B., Bretz, L., Towns, M. H. (2008). Characterizing the Level of Inquiry in the Undergraduate Laboratory. Journal of College Science Teaching, 38(1), 52-58.

Budur, E. L. (2013). Integrasi Pendidikan Karakter Melalui Inkuiri dengan Lesson Study dalam Pembelajaran Biologi untuk Meningkatkan Sikap Ilmiah dan Hasil Belajar Kognitif Siswa Kelas VII SMPN I Singosari. Jurnal Pendidikan Sains, 1(2), 171-177.

Dianti, P. (2014). Integrasi Pendidikan Karakter dalam Pembelajaran Pendidikan Kewarganegaraan untuk Mengembangkan Karakter Siswa. Jurnal Pendidikan Ilmu Sosial, 23(1), 58-68.

Fitriana, M., Haryani, S. (2016). Penggunaan Strategi Pembelajaran Inkuiri untuk Meningkatkan Metakognisi Siswa SMA. Jurnal Inovasi Pendidikan Kimia, 10(1), 1702-1711.

Hasanah, U. (2016). Model-model Pendidikan Karakter di Sekolah. Al-Tadzkiyyah: Jurnal Pendidikan Islam, 7(1), 18-34.

Hussain, A., Azeem, M., Shakoor, A. (2011). Physics Teaching Methods: Scientific Inquiry Vs Traditional Lecture. International Journal of Humanities and Social Science, 1(19), 269-276.

Ihsan, H. (2015). Validitas Isi Alat Ukur Penelitian Konsep dan Panduan Penilaiannya. Pedagogia: Jurnal Ilmu Pendidikan, 13(2), 266-273.

Jufri, A. W. (2017). Belajar dan Pembelajaran Sains. Bandung: Pustaka Reka Cipta.

Laksana, S. D. (2015). Urgensi Pendidikan Karakter Bangsa di Sekolah. Muaddib, 5(1), 167-184.

Larlen. (2013). Persiapan Guru Bagi Proses Belajar Mengajar. Pena, 3(1). 81-91.

Maemunah. (2012). Aspek-Aspek dalam Pendidikan Karakter. Forum Tarbiyah, 10(1), 30-42.

Makhrus, M. \& Hadiprayitno, G. (2012). Penerapan Perangkat Pembelajaran Fisika Berorientasi Pembelajaran IPA Terpadu Tipe Connected. Jurnal Pendidikan dan Pembelajaran: JPP UM. 19(2), 237-242.

Marzuki. (2012). Pengintegrasian Pendidikan Karakter dalam Pembelajaran di Sekolah. Jurnal Pendidikan Karakter, 2(1). 33-44.

Masruroh., Widodo, W., \& Hidayat, M. T. (2016). Pengembangan Perangkat Pembelajaran Berbasis Inkuiri Terbimbing untuk Meningkatkan Kreativitas Ilmiah Siswa SMP. pendidikan Sains Pascasarjana Universitas Negeri Surabaya, 5(2), 1061-1067.

Muhali. (2019). Pembelajaran Inovatif Abad ke-21. The 1st National Conference on Education, Social Science, and Humaniora. FPMIPA IKIP Mataram. pp 21-42.

Muryati, S. (2013). Pendekatan Inkuiri Moral Sebagai Alternatif Metode Pendidikan Karakter Siswa di Smp. Majalah Ilmiah Pawiyatan, XX(4), 1-14.

Nieveen, N. (1999). Prototyping to Reach Product Quality. London: Kluwer Academic Plubishers. University of Twente.

P21 (Partnership for 21st Century Learning), (2015). Framework Definitions. di Akses Tenggal 8 November 2019. https://files.eric.ed.gov/fulltext.ED519462.pdf

Permendikbud. (2016). Kompetensi Inti dan Kompetensi Dasar Pelajaran pada Kurikulum 2013 pada pendidikan dasar dan pendidikan menengah. Ttd Anies Baswedan. 
Permendikbud. (2018). Kompetensi Inti dan Kompetensi Dasar Pelajaran pada Kurikulum 2013 pada pendidikan dasar dan pendidikan menengah. Ttd Muhadjir Effendy.

Rajabi, M., Ekohariadi., Buditjahjanto, I.G.P.A. (2015). Pengembangan Perangkat Pembelajaran Instalasi Sistem Operasi dengan Model Pembelajaran Berbasis Proyek. Jurnal Pendidikan Vokasi: Teori dan Praktek, 3(1), 48-54.

Sadia, I.W., Arnyana, I.P.B., Muderawan, I.W. (2013). Model Pendidikan Karakter Terintegrasi Pembelajaran Sains. Jurnal Pendidikan Indonesia, 2(2), 209-220.

Scott, C. L. (2015). The Futures of Learning 2 "What Kind of Learning For the 21st Century". United Nations Educational, Scientific and Cultural Organization.

Suhartini, E., Supardi, Z. A., Imam., Agustini, R. (2016). Pengembangan Perangkat Pembelajaran Model Inkuiri Terbimbing Berbantuan Teknik Mind Mapping untuk Meningkatkan Penguasaan Konsep dan Kemampuan Berpikir Kreatif Siswa SMP. Pendidikan Sains Pascasarjana Universitas Negeri Surabaya, 5(2), 892-902.

Wenning, J. C. (2015). Teaching the Nature of Science. Seminar Internasional Universitas Negeri Malang.

Wijaya, E. Y., Sudjimat, D. A., Nyoto, A. (2016). Transformasi Pendidikan abad 21 sebagai Tuntutan Pengembangan Sumber Daya Manusia di Era Global. Prosiding Seminar Nasional Pendidikan Matematika Universitas Kanjuruhan Malang. pp. 263-278.

Zubaidah, S. (2019). Pendidikan Karakter Terintegrasi Keterampilan Abad ke-21. The $1^{\text {st }}$ National Conference on Education, Social Science, and Humaniora. FPMIPA IKIP Mataram. pp 1-20. 